\title{
ANALISIS PERBANDINGAN FASILITAS APLIKASI MOBILE BANKING BANK SYARIAH MANDIRI KCP. BENGKALIS DENGAN BANK MANDIRI KC. BENGKALIS
}

\author{
Miftahuddin, Decky Hendarsyah \\ Sekolah Tinggi Ilmu Ekonomi (STIE) Syariah Bengkalis \\ Email: miftahuddin386@gmail.com,deckydb@gmail.com
}

\begin{abstract}
ABSTRAK
Mobile Banking adalah layanan perbankan menggunakan alat komunikasi bergerak seperti handphone dengan menyediakan banyak fasilitas untuk bertransaksi perbankan melalui aplikasi pada handphone. Penelitian ini dilakukan untuk mengetahui Perbandingan Fasilitas Aplikasi Mobile Banking Bank Syari'ah Mandiri KCP. Bengkalis dengan Bank Mandiri KC. Bengkalis. Metode penelitian yang digunakan dalam penelitian ini adalah metode deskripktif kualitatif dengan cara membandingkan fasilitas, tarif, jumlah nasabah pengguna dan keamanan Mobile Banking kedua bank tersebut, kemudian bagaimana penggunaan Mobile Banking dilihat dari perspektif syariah. Setelah diteliti didapat bahwa fasilitas aplikasi Mobile Banking Bank Mandiri lebih baik dari pada Bank Syariah Mandiri. Sedangkan Mobile Banking dalam perspektif syariah boleh dilakukan karena tidak menimbulkan kemudharatan melainkan suatu hal yang mendatangkan banyak keuntungan.
\end{abstract}

Kata Kunci: Mobile Banking, Bank Syariah Mandiri, Bank Mandiri.

\section{ABSTRACT}

Mobile Banking is a banking service using mobile communication tools such as mobile phones by providing many facilities for banking transactions through applications on mobile phones. This research was conducted to find out the Comparison of Bank Syariah Mandiri Bengkalis Branch Office Mobile Banking Application Facilities with Bank Mandiri Bengkalis Branch Office. The research method used in this study is a qualitative descriptive method by comparing the facilities, rates, number of user customers and the security of the Mobile Banking of both banks, then how to use Mobile Banking from an Islamic perspective. After being investigated, it was found that Bank Mandiri Mobile Banking application facilities were better than Bank Syariah Mandiri. Whereas Mobile Banking in an Islamic perspective may be done because it does not cause harm but it is something that brings many benefits.

Keywords: Mobile Banking, Bank Syariah Mandiri, Bank Mandiri.

\section{PENDAHULUAN}

Indonesia memiliki fenomena yang menarik mengenai Mobile Banking saat ini. Nasabah sudah merasakan kenyamanan dengan layanan yang ada, layanan perbankan yang dikenal dengan istilah E-Banking memungkinkan nasabah untuk 
mendapatkan informasi dan menyelesaikan berbagai urusan perbankan secara cepat, mudah dan tanpa batas tempat dan waktu (Sulistriyani, 2013). Kemajuan dan perkembangan teknologi informasi yang pesat telah mempengaruhi industri perbankan, perusahaan yang ingin maju dan berkembang harus memiliki keunggulan kompetitif antara lain adalah dengan mengadopsi fasilitas teknologi informasi dan memberikan layanan kepada konsumen.

Dalam industri perbankan, penggunaan teknologi informsi (Mobile Banking) merupakan salah satu bentuk layanan dilakukan dengan tujuan untuk mempermudah nasabah melakukan transaksi keuangan (perbankan). Layanan yang baik akan membentuk sikap positif nasabah terhadap perusahaan dan niat untuk tetap menggunakan jasa layanan jasa perbankan yang bersangkutan. Mobile Banking secara umum adalah saluran distribusi Bank untuk mengakses rekening yang dimiliki nasabah melalui teknologi penyampaian data melalui ponsel atau general package radio service (gprs) dengan sarana telepon seluler (ponsel).

Mobile Banking diartikan sebagai fasilitas bagi nasabah bank untuk dapat melakukan aktifitas perbankan mereka secara lebih leluasa, dimana saja, kapan saja, dan tanpa harus secara fisik mengunjungi bank tersebut. Manfaat Mobile Banking dapat digunakan untuk transaksi-transakasi pemindah buku sesama bank, transfer antar bank, informasi saldo, mutasi rekening hingga 20 transaksi (Jumaini 2012).

Teknologi membuat segala sesuatu menjadi lebih praktis dan mudah untuk dilakukan, sehingga pekerjaan manusia yang sebelumnya sulit untuk dikerjakan, bisa teralisasi dengan mudah, cepat, dan efisien. Salah satu contoh teknologi yang sering digunakan adalah internet. Kehadiran teknologi internet memberikan manfaat komunikasi tanpa batas dan waktu. Penggunaan internet tidak hanya untuk mencari informasi saja, tetapi juga untuk transaksi bisnis yang disebut dengan E-Commerce.

Penggunaan teknologi informasi dan komunikasi didunia perbankan relatif lebih maju dibandingkan sektor lainnya. Berbagai jenis teknologi diantaranya Anjungan Tunai Mandiri atau dalam bahasa Inggris Automated Teller Machine (ATM), Banking Application System, Real Time Gross Settlement System, Sistem Kliring Elektronik dan Internet Banking. Mobile Banking merupakan layanan perbankan yang berfungsi untuk memudahkan nasabah dalam melakukan transaksi perbankan tanpa perlu datang ke bank atau ATM kecuali penarikan uang cash. Keunggulan Mobile Banking yaitu nasabah dapat melakukan transaksi dimana saja dan kapan saja tanpa dibatasi waktu. Layanan pada Mobile Banking meliputi: transaksi finansial, transaksi non finansial, transfer dana, cek saldo dan pembayaran tagihan yang dilakukan lewat telepon seluler. (Sebayang 2017)

Bank umum (konvensional) merupakan bank yang paling banyak berada di Indonesia. Bank umum memiliki kegiatan pemberian jasa yang paling lengkap dan dapat beroperasi di seluruh wilayah Indonesia. Dalam menentukan harga dan mencari keuntungan, bank yang berdasarkan prinsip konvensional menggunakan dua metode, yaitu Spread Based dan Fee Based (Angraini 2012)

Bank syariah adalah suatu lembaga keuangan yang usaha pokoknya memberikan kredit, pembiayaan dan jasa-jasa lainnya dalam lalu lintas pembayaran serta peredaran uang yang pengoperasiannya disesuaikan dengan prinsip-prinsip Islam (UU No. 21/2008). Sistem perbankan syariah di Indonesia di awali pada tahun 1992 dengan diterbitkannya Undang-Undang No.7 Tahun 1992 
tentang bank dengan sistem bagi hasil. Kemudian di tahun 1992 juga telah lahir bank syariah pertama sebagai pelopor yang tidak menggunakan sistem bunga seperti di bank konvensional, melainkan menggunakan sistem bagi hasil yaitu Bank Muamalat Indonesia (BMI). Kebanyakan dari pelanggan, terutama nasabah bank, yang menginginkan suatu pelayanan yang sederhana dan praktis sehingga dapat bertransaksi tanpa harus mencatat terlebih dahulu dan tanpa membuang waktu mengantri. Pelayanan manual ini dirasa kurang efisien, karena secara riil kesibukan orang sebagai nasabah pada saat ini semakin meningkat. (Machmud et al. 2010)

Mandiri Mobile adalah layanan Mobile Banking pada Smartphone (Blackberry, Android, dan iPhone) dengan tampilan menu yang menarik dan mudah digunakan. Mandiri Mobile dapat melakukan transaksi finansial (transfer, pembayaran, pembelian, dll), transaksi non finansial (cek saldo, cek histori transaksi, dll), informasi lokasi cabang/ATM, informasi kurs dan fitur-fitur menarik lainnya).

Bank Syariah Mandiri (BSM) Mobile Banking adalah salah satu saluran distribusi yang dimiliki oleh Bank Syariah Mandiri untuk mengakses rekening yang dimiliki nasabah dengan menggunakan teknologi GPRS/EDGE/3G/4G dan wifi melalui Smartphone.

Adapun tujuan penelitian ini adalah sebagai berikut:

1. Untuk mengetahui Fasilitas Mobile Bangking yang ada Pada Bank Mandiri Syariah Kantor Cabang Pembantu Dengan Mandiri Kantor Cabang Bengkalis.

2. Untuk mengetahui Fasilitas Mobile Banking yang terbaik di antara Bank Mandiri Syariah Kantor Cabang Pembantu Dengan Mandiri Kantor Cabang Bengkalis.

3. Untuk mengetahui dasar hukum secara islam Mobile Banking dalam bertransakasi serta dalam dasar hukum perbankan.

\section{TINJAUAN PUSTAKA}

\section{Mobile Banking}

Mobile Banking merupakan sebuah fasilitas atau layanan perbankan menggunakan alat komunikasi bergerak seperti handphone dengan penyediaan fasilitas untuk bertransaksi perbankan melalui aplikasi pada handphone. Dengan adanya handphone dan layanan Mobile Banking transaksi perbankan yang biasanya dilakukan secara manual, artinya kegiatan yang sebelumnya dilakukan nasabah dengan mendatangi bank, kini dapat dilakukan tanpa harus mengunjungi gerai bank,hanya dengan menggunakan handphone nasabah dapat menghemat waktu dan biaya. Layanan Mobile Banking memberikan kemudahan kepada para nasabah untuk melakukan transaksi perbankan seperti cek saldo, transfer antar rekening, pembayaran tagihan, isi pulsa, dan lain-lain. (Wibiadila 2016)

\section{Internet Banking}

Internet Banking secara ringkas dapat diartikan sebagai aktifitas perbankan di Internet. Pengertian Internet Banking dapat didefinisikan sebagai berikut (Hendarsyah 2012, 14):

1. Menurut David Whiteley: 
"Internet Banking adalah salah satu jasa pelayanan yang diberikan bank kepada nasabahnya dengan maksud agar nasabah dapat mengecek saldo rekening dan membayar tagihan selama 24 jam tanpa perlu datang ke kantor cabang".

2. Menurut Mary J. Cronin:

"Internet Banking adalah aplikasi layanan keuangan yang memungkinkan lembaga keuangan untuk menawarkan produk dan layanan perbankan tradisionalnya seperti cek saldo tabungan dan rekening pasar uang serta sertifikat deposito melalui internet".

3. Menurut Mahmood Shah dan Steve Clarke:

"Penyediaan informasi mengenai bank dan layanannya melalui halaman website di World Wide Web (WWW). Dimana layanan yang disediakan berupa akses pelanggan ke rekening, dapat mentransfer antar rekening yang berbeda dan dapat melakukan pembayaran atau mengajukan pinjaman melalui channel elektronik".

Internet Banking mempunyai tiga tingkatan definisi berdasarkan yang ditawarkan bank kepada nasabah yaitu sebagai berikut: (Hendarsyah 2012, 15)

1. Tingkat Entry:

Merupakan definisi yang paling sederhana, dimana pada tingkatan ini hanya terdapat informasi statistik mengenai bank yang bersangkutan, jasa atau produk apa saja yang ditawarkan oleh bank dan juga pelayanan dasar seperti perkiraan pembayaran pinjaman. Pada tingkatan ini, hanya menampilkan situs yang bagus pada web browser.

2. Tingkat Intermediate:

Pada tingkatan ini menawarkan seluruh layanan informasi keuangan seperti yang ditawarkan pada tingkat entry dan ditambah dengan layanan interaktif dasar dengan kemampuan dasar yaitu antara lain: perhitungan pembayaran kredit dan kemampuan untuk menampilkan rincian simpanan nasabah.

3. Tingkat Advanced:

Pada tingkatan ini Internet Banking dapat didefinisikan sebagai tingkat yang paling lengkap layanannya, dimana layanan yang ditawarkan adalah seluruh fungsionalitas dan keamanan. Pada tingkatan ini nasabah bank dapat melakukan transfer dana antar bank, membayar tagihan dan membuka simpanan baru.

\section{Konsep Keamanan Internet Banking}

Keamanan merupakan sebagai kondisi atau kualitas yang bebas dari ketakutan, kecemasan, atau kepedulian. Jaringan komunikasi yang aman, dapat didefinisikan sebagai suatu jaringan dimana pengguna tidak merasakan ketakutan atau kecemasan sewaktu menggunakan jaringan. Komputer dan sistem jaringan yang tidak terbatas telah memberi kesempatan untuk mengurangi biaya, meningkatkan efisiensi dan meningkatkan pendapatan. Sayangnya, ketergantungan tersebut menimbulkan risiko baru yang mengancam keamanan komputer dan sistem jaringan. Dengan demikian muncullah suatu tantangan baru untuk melindungi keamanan komputer dan sistem jaringan dari berbagai macam serangan keamanan. Terdapat tiga komponen dasar sebagai pertimbangan dalam 
perancangan dan pembahasan sistem keamanan diantaranya adalah sebagai berikut (Hendarsyah 2012, 14):

1. Confidentiality:

Confidentiality adalah penyembunyian informasi atau sumber daya yang berkaitan dengan pencegahan akan pengaksesan terhadap informasi atau sumber daya yang dilakukan oleh pihak yang tidak berhak.

2. Integrity:

Integrity merupakan keandalan data atau sumber daya dan biasanya dirumuskan untuk mencegah perubahan yang tidak sah. Integritas mencakup integritas data (isi dari informasi) dan integritas asli (sumber data, sering disebut otentikasi). Dengan demikian integrity berkaitan dengan pencegahan modifikasi informasi yang dilakukan oleh pihak yang tidak berhak.

3. Availability:

Availability merupakan kemampuan untuk menggunakan informasi atau sumber daya yang diinginkan. Availability adalah aspek yang penting dalam mendesain sistem karena suatu sistem yang tidak memiliki availability sama buruknya dengan tidak ada sistem sama sekali. Availability dapat melakukan pencegahan akan penguasaan informasi atau sumber daya oleh pihak yang tidak berhak.

Model saat ini diadopsi dalam sistem Internet Banking didasarkan pada beberapa lapisan keamanan, yang terdiri atas beragam solusi paralel dan mekanisme yang bertujuan untuk melindungi aplikasi perbankan dan data nasabah, menyediakan identifikasi, otentikasi dan otorisasi. Diantara model keamanan Internet Banking adalah sebagai berikut (Hendarsyah 2012, 19):

1. Digital Certificates (Sertifikat Digital):

Sertifikat digital digunakan untuk otentikasi atau keabsahan antara pengguna dan sistem perbankan itu sendiri. Otentikasi ini tergantung pada keberadaan Public Key Infrastructure (PKI) atau infrastuktur kunci publik dan Certificate Authority (CA) atau sertifikat otoritas, yang dipercayakan kepada pihak ketiga untuk membuktikan validitas sertifikat digital mereka.

2. One-Time Password Tokens:

One-Time Password Tokens umumnya digunakan sebagai otentikasi kedua, yang dapat diminta dalam kondisi acak. Jenis perangkat ini membuat data otentikasi yang berguna untuk mengatasi serangan keamanan dengan cara menggunakan password secara dinamis atau berubah-ubah dan password hanya dapat digunakan sekali.

3. One-Time Password Cards:

One-Time Password Cards merupakan model yang lebih murah untuk menghasilkan password yang dinamis, juga menyediakan otentikasi kedua. Namun dalam beberapa sistem perbankan, password yang dihasilkan oleh kartu OTP (One Time Password) dapat digunakan kembali beberapa kali sebelum dibuang, ini rentan terhadap serangan keamanan jangka pendek.

4. Browser Protection:

Pada model ini, sistem dijamin pada tingkat web browser Internet, yang digunakan untuk mengakses Internet Banking. Para pengguna browser dilindungi dari malware dengan cara memantau wilayah memori yang 
dialokasikan oleh browser untuk mendeteksi malware dan menghalangi pencurian informasi yang sensitif seperti user name dan password.

5. Virtual Keyboards:

Keyboard virtual yang dikembangkan untuk menggagalkan penggunaan key loggers (menangkap informasi yang diketik kedalam perangkat lunak). Alat ini biasanya merupakan perangkat lunak yang berbasiskan Java dan Kriptografi yang mendukung web browser yang berbeda.

6. Device Registering:

Metode ini membatasi akses ke sistem perbankan melalui perangkat yang belum dikenal atau terdaftar pada sistem. Perangkat ini menggunakan scan sidik jari untuk identifikasi penggunanya.

7. CAPTCHA:

Completely Automated Public Turing test to tell Computers and Humans Apart (CAPTCHA) adalah metode baru yang diadopsi pada beberapa sistem perbankan yang bertujuan untuk menangkal serangan otomatis terhadap sesi atau halaman konfirmasi pada website. Metode ini mengharuskan pengguna yang sah untuk memasukkan informasi yang ditampilkan dalam gambar atau audio secara acak dan sulit bagi program otomatis (robot otomatis) untuk mengenali dan memproses gambar atau audio tersebut sebagai input konfirmasi.

8. Short Message Service (SMS):

Short Message Service (SMS) merupakan metode yang diterapkan pada Internet Banking untuk memberitahu nasabah bank tentang transaksi yang sedang dilakukan melalui SMS. SMS ini menyediakan saluran otentikasi kedua untuk transaksi perbankan, dimana sistem Internet Banking mengirimkan kepada pengguna (nasabah bank) satu set karakter melalui SMS yang harus diinformasikan untuk otoritas konfirmasi pada proses transaksi melalui Internet Banking.

9. Device Identification:

Device Identification biasanya diterapkan bersama-sama dengan Device Registering tetapi juga digunakan sebagai solusi yang berdiri sendiri dalam sistem Internet Banking yang bertujuan untuk memfasilitasi akses nasabah bank. Model identifikasi ini didasarkan pada karakteristik fisik dari perangkat yang digunakan oleh nasabah bank dengan cara mengidentifikasi asal usul dan riwayat informasi perangkat tersebut.

10. Positive Identification:

Positive Identification adalah suatu model di mana nasabah bank diminta untuk memasukkan beberapa informasi rahasia yang hanya diketahui nasabah tersebut dalam rangka untuk mengidentifikasi dirinya. Hal ini diterapkan sebagai metode otentikasi kedua.

11. Pass-Phrase:

Pass-Phrase ini adalah model keamanan berdasarkan informasi yang dimiliki oleh nasabah bank. Hal ini biasanya digunakan sebagai metode otentikasi kedua dalam transaksi yang melibatkan pergerakan uang.

12. Transaction Monitoring:

Saat ini pada sistem Internet Banking, masing-masing bank menggunakan teknik yang berbeda-beda. Mulai dari teknik kecerdasan buatan, analisis riwayat transaksi dan metode lain yang digunakan untuk mengidentifikasi 
pola-pola penipuan dalam transaksi perbankan sebagai pendekatan untuk pemantauan transaksi perbankan.

\section{Bank Konvensional}

Kondisi persaingan antar bank yang begitu ketat dan ancaman bagi bank-bank yang bermasalah membuat para banker untuk bekerja keras untuk mendapatkan total asset yang lebih tinggi. Bank milik pemerintah misalnya sepeti Bank Mandiri yang memiliki Asset besar. Bank berasal dari kata italia banco yang artinya bangku. Bangku inilah yang dipergunakan oleh bankir untuk melayani operasionalnya kepada para nasabah. Istilah bangku secara resmi dan populer menjadi Bank. Bank termasuk perusahaan Industri Jasa kedua produknya hanya memberikan pelayanan jasa kepada masyarakat. Agar pengertian bank menjadi jelas, Bank adalah badan usaha yang menghimpun dan menyalurkannya kepada masyarakat dalam bentuk kredit dalam rangka meningkatkan taraf hidup rakyat banyak, Perbankan adalah segala sesuatu yang menyangkut tentang bank, mencakup kelembagaan, kegiatan usaha, serta cara dan proses dalam melaksanakan kegiatan ushanya (Hasibuan 2015).

Bank dikenal sebagai lembaga keuangan yang kegiatan utamanya menerima simpanan giro, tabungan dan deposito. Kemudian bank juga dikenal sebagai tempat untuk meminjam uang (kredit) bagi masyarakat yang membutuhkannya. Di samping itu, bank juga dikenal sebagai tempat untuk menukar uang, memindah uang atau menerima segala macam bentuk pembayaran dan setoran seperti pembayaran listrik, telepon, air, pajak, uang kuliah, dan pembayaran lainnya. Pengertian bank menurut Undang-Undang No. 10 tahun 1999 tentang perubahan atas Undang-Undang No. 7 tahun 1992 tentang perbankan adalah badan usaha yang menghimpun dana dari masyarakat dalam bentuk simpanan dan menyalurkannya kepada masyarakat dalam bentuk kredit dan/atau bentuk-bentuk lainnya dalam rangka meningkatkan taraf hidup rakyat banyak (Kasmir 2013, 24).

Di Indonesia, menurut jenisnya bank terdiri dari Bank Umum dan Bank Perkreditan Rakyat. Dalam Pasal 1 ayat 3 Undang-Undang No. 10 Tahun 1998 menyebutkan bahwa bank umum adalah bank yang melaksanakan kegiatan usaha secara konvensional dan/atau berdasarkan prinsip syariah yang dalam kegiatannya memberikan jasa dalam lalu lintas pembayaran. Bank konvensional dapat didefinisikan seperti pada pengertian bank umum pada pasal 1 ayat 3 UndangUndang No. 10 tahun 1998 dengan menghilangkan kalimat "dan atau berdasarkan prinsip syariah", yaitu bank yang melaksanakan kegiatan usaha secara konvensional yang dalam kegiatannya memberikan jasa dalam lalu lintas pembayaran.Bank umum (konvensional) merupakan bank yang paling banyak beredar di Indonesia. Bank umum memiliki kegiatan pemberian jasa yang paling lengkap dan dapat beroperasi di seluruh wilayah Indonesia. Dalam menentukan harga dan mencari keuntungan, bank yang berdasarkan prinsip konvensional menggunakan dua metode, yaitu (Angraini 2012):

1. Menetapkan bunga sebagai harga untuk produk simpanan seperti giro, tabungan, maupun deposito. Demikian pula untuk produk pinjamannya (kredit) juga ditentukan berdasarkan tingkat suku bunga tertentu. Penentuan harga ini dikenal dengan istilah Spread Based. 
2. Untuk jasa-jasa bank lainnya, pihak perbankan menerapkan berbagai biaya-biaya dalam nominal atau prosentase tertentu. System pengenaan biaya ini dikenal dengan istilah Fee Based.

\section{Bank Syariah}

Islam adalah agama yang ajarannya bersifat universal, artinya ajaran yang di bawa islam itu bersifat menyeluruh dan menyacakup pada segala bidang kehidupan. Dengan sistem ajaran tersebut, lembaga keuangan muncul sebagai sarana untuk aktivitas konsumsi, simpanan, dan investasi. Sistem perbankan syariah di indonesia diawali pada tahun 1992 dengan diterbitkannya undangundang No.7 tahun 1992 tentang bak dengan sistem bagi hasil (Muhammad 2014, 36)

Menurut Pasal 1 Undang - Undang No. 21 Tahun 2008, Bank adalah badan usaha yang menghimpun dana masyarakat dalam bentuk simpanan dan menyalurkannya kepada masyarakat dalam bentuk kredit dan/atau bentuk-bentuk lainnya dalam rangka meningkatkan taraf hidup rakyat banyak. Sedangkan menurut pasal 1 Undang - Undang No. 4 Tahun 2003 tentang Perbankan, Bank adalah Bank Umum dan Bank Perkreditan Rakyat yang melaksanakan kegiatan usaha secara konvensional atau berdasarkan prinsip syariah yang dalam kegiatannya tidak memberikan jasa dalam lalu lintas pembayaran (Muhammad 2014, 37).

Pengertian syariah secara etimologis berarti sumber air yang mengalir, kemudian kata tersebut digunakan untuk pengertian : hukum-hukum allah yang diturunkannya untuk umat manusia (Hamba Allah). Kata syariat dalam berbagi bentuknya diungkapkan dalam beberapa ayat al-quran, yang dalam ayat tersebut syariah berarti peraturan (Mardani 2015, 8). Terdapat pada Allah berfirman dalam surat Al-Maidah ayat 48: (Mardani 2015, 9; Kemenag 2004)

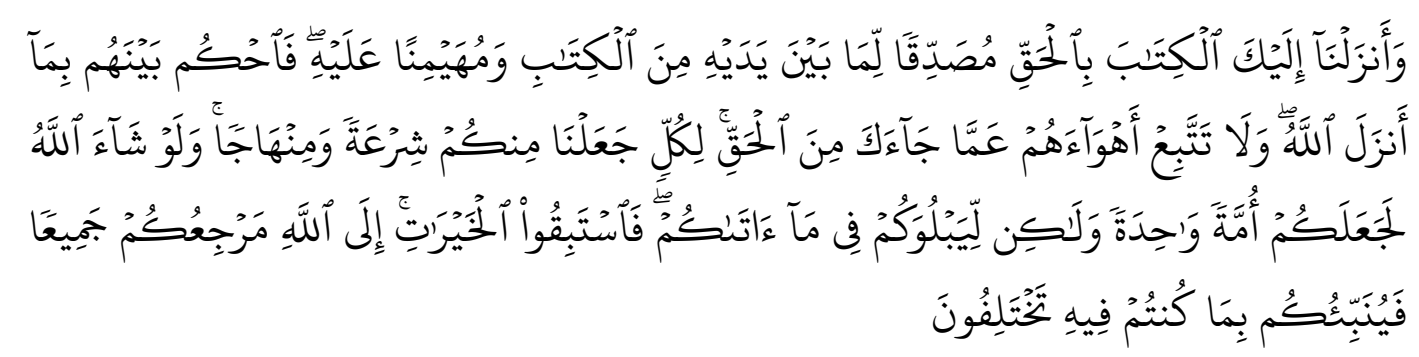

Artinya: "Dan Kami telah turunkan kepadamu Al Quran dengan membawa kebenaran, membenarkan apa yang sebelumnya, Yaitu Kitab-Kitab (yang diturunkan sebelumnya) dan batu ujian terhadap Kitab-Kitab yang lain itu; Maka putuskanlah perkara mereka menurut apa yang Allah turunkan dan janganlah kamu mengikuti hawa nafsu mereka dengan meninggalkan kebenaran yang telah datang kepadamu. untuk tiap-tiap umat diantara kamu, Kami berikan aturan dan jalan yang terang. Sekiranya Allah menghendaki, niscaya kamu dijadikan-Nya satu umat (saja), tetapi Allah hendak menguji kamu terhadap pemberian-Nya kepadamu, Maka berlomba-lombalah berbuat kebajikan. hanya kepada Allah-lah kembali kaтu semuanya, lalu diberitahukan-Nya kepadamu apa yang telah kamu perselisihkan itu" 
Bank syariah adalah bank yang dalam aktivitasnya, baik penghimpunan dana maupun penyaluran dana memberikan imbalan atas dasar prinsip syariah, yaitu bagi hasil dan jual beli. Bank Syariah Mandiri (BSM) merupakan bank milik pemerintah pertama yang melandaskan operasionalnya pada prinsip syariah. Secara struktural, Bsm berasal dari Bank Susila Bakti (BSB), sebagai salah satu anak perusahaan di lingkup Bank Mandiri (Ex Bdn), yang kemudian dikonversikan menjadi Bank Syariah secara penuh. Dalam rangka melancarkan proses konversi menjadi bank syariah, bsm menjalin kerja sama dengan tazkia institute, terutama dakam bidang pelatihan dan pendapingan konverensi (Antonio 2008, 26).

Dari pengertian diatas, dapat disimpulkan bahwa Bank Syariah merupakan lembaga keuangan yang menghindari riba yang lazim digunakan pada Bank konvensional, karena usaha pokoknya adalah memberikan pembiayaan dan jasa lainnya dalam lalu lintas pembayaran serta peredaran uang yang beroperasi mengacu pada Al-Qur'an dan Al-Hadist. Larangan riba dalam Al-Quran yaitu Riba diharamkan dengan dikaitkan kepada suatu tambahan yang berlipat ganda. Para ahli tafsir berpendapat bahwa pengambilan bunga dengan tingkat yang cukup tinggi merupakan fenomena yang banyak dipraktekkan (Antonio 2008, 26).

Allah berfirman dalam surat Al-Imran ayat 130: (Kemenag 2004)

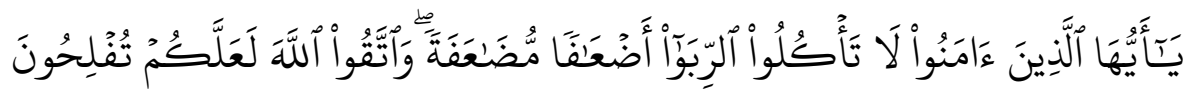

Artinya: "Hai orang-orang yang beriman, janganlah kamu memakan riba dengan berlipat ganda dan bertakwalah kamu kepada Allah supaya kamu mendapat keberuntungan”.

Sedangkan larangan riba dalam hadist riwayat Muslim yang diriwayatkan oleh Abu Said al-Khurdi ra: (Machmud et al. 2010, 3)

"Jika emas dijual dengan emas, perak dijual dengan perak, gandum dijual dengan gandum, sya'ir (salah satu jenis gandum) dijual dengan sya'ir, kurma dijual dengan kurma, dan garam dijual dengan garam, maka jumlah (takaran atau timbangan) harus sama dan dibayar kontan (tunai). Barangsiapa menambah atau meminta tambahan, maka ia telah berbuat riba. Orang yang mengambil tambahan tersebut dan orang yang memberinya sama-sama berada dalam dosa." (HR. Muslim no. 1584)

Menurut Qardhawi, hikmah aksplisit yang tampak jelas dibalik pelarangan riba adalah perwujudan persamaan yang adil diantara pemilik harta (modal) dengan usaha, serta pemikulan resiko dan akibatnya secara berani dan penuh rasa tanggung jawab. Prinsip keadilan dalam islam ini tidak memihak kepada salah satu pihak, melainkan keduanya berada pada posisi yang seimbang. Sumber hukum transaksi dalam islam adalah Al-Qur'an, As-Sunnah, Ijtihad (Termasuk Menggunakan Instrumen Ijma', Qiyas ,Al-Maslahah Al-Mursalah, Dan Lain-Lain Yang Diakui Sebagi Instrumen Ijtihad). Disamping itu, terdapat legal maxim (kaidah fiqihiyyah) yang merupakan prinsip umum yang bisa dijadikan panduan umum dalam pembangunan hukum islam, terutama apabila terdapat masalh baru yang memerlukan keputusan hukum secara cepat. Berikut ini akan dijelaskan beberapa panduan yang digariskan al-qur'an dan as-sunnah serta kaidah yang 
diformulasikan para ulama fiqig dalam bentuk kaidah fiqhiyah mengenai prinsipprinsip pokok transaksi dalam Islam (Machmud et al. 2010, 3).

\section{Mobile Banking dari Perspektif Islam}

Berdasarkan ruang lingkup ekonomi, maka islam adalah sebuah agama yang mengatur segala aspek kehidupan, tentu saja mempunyai cara untuk perekonomian dan menarik yang baik dan sesuai dengan aturan-aturan agama islam, ditinjau dari aspek aksionologinya tinjauan ekonomi islam adalah setiap kegiatan manusia didasarkan kepada pengabdian kepada Allah, dalam rangka melaksanakan tugas dari Allah untuk memakmurkan bumi, maka dalam perekonomian umat Islam harus mengutamakan keharmonisan dan pelestarian alam. Dalam transaksi Mobile Banking terbukti aman dengan adanya sistem proteksi yang berlapis serta memiliki perlindungan hukum yang banyak pula sehingga hak-hak nasabah dalam transaksi Mobile Banking dapat terlindungi dan tidak dapat diperlakukan semena-mena tanpa pertanggung jawaban. Dalam akad perjanjian Mobile Banking telah sesuai dengan syarat sahnya perjanjian dengan terpenuhinya rukun dan syarat akad (perjanjian). Mobile Banking termasuk Akad Wakalah, mengenai lafal Ijab Qabulnya (Trisni 2012). Wakalah atau wikalah berarti penyerahan, pendelegasian, atau pemberian mandat. Dalam bahasa arab, hal ini dapat dipahami sebagai at-tafwidh. Akan tetapi, yang dimaksud sebagai alwakalah adalah pelimpahan kekuasaan oleh seseorang kepada yang lain dalam hal-hal yang diwakilkan (Antonio 2008).

Allah berfirman dalam Al-Quran sebagai berikut (Kemenag 2004):

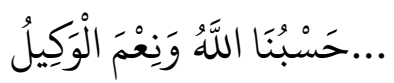

Artinya: “...Cukuplah Allah sebagai penolong kami dan dia sebaik-baik pemelihara.” (Al-Quran, Ali Imran: 173)

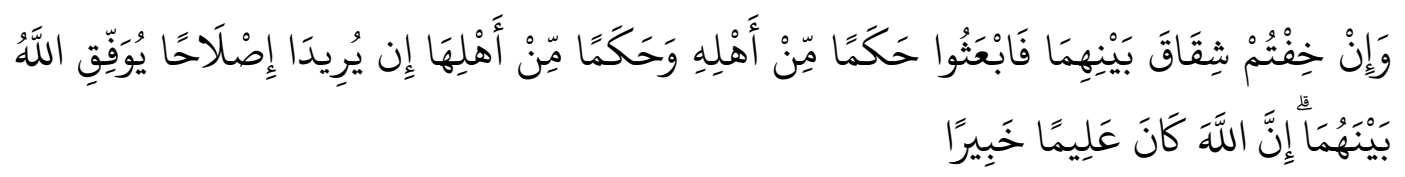

Artinya: "Dan jika kamu khawatir terjadi persengketaan antara keduanya, maka kirimkanlah seorang utusan dari keluarga laki-laki dan bahkan keluarga wanita. Jika keduanya bermaksud mengadakan perbaikan, niscaya Allah memberi taufik kepada suami istri itu. Sungguh Allah Maha Mengetahui, Maha Teliti" (AlQuran, An-Nissa: 35)

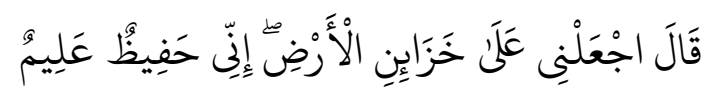

Artinya: "Berkatalah Yusuf," Jadikanlah Aku bendaharawan negara (Mesir); sesungguhnya aku adalah orang yang pandai menjaga lagi berpengetahuan." (Al-Quran, Yusuf: 55)

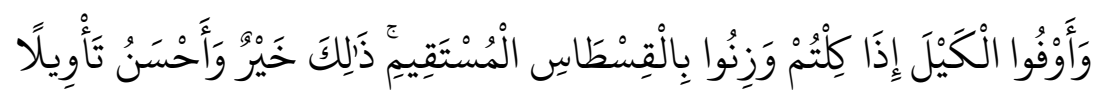


Artinya: "Dan sempurnakanlah takaran apabila kamu menakar, dan timbanglah dengan neraca yang benar. Itulah yang lebih utama (bagimu) dan lebih baik akibatnya”. (Al-Quran, Al-Isra: 35)

\section{METODE PENELITIAN}

Teknik pengumpulan data yang dilakukan adalah: wawancara, dokumentasi, studi pustaka dan observasi, sedangkan dalam menganalisis data, yang digunakan dalam penelitian ini adalah analisis deskriptif. Analsisis deskriptif yaitu menganalisis data dengan cara mendeskripsikan atau menggambarkan data yang telah terkumpul. Kemudian mengolah data-data yang diperoleh dari Bank Mandiri KC. Bengkalis dan Bank Mandiri Syariah KCP. Bengkalis, serta didukung dengan berbagai teori mengenai masalah penelitian.

\section{HASIL DAN PEMBAHASAN PENELITIAN}

Berdasarkan Fitur Aplikasi Mobile Banking Bank Syariah Mandiri dan Bank Mandiri dapat dipaparkan sebagai berikut:

\section{Tabel 1}

Fitur-Fitur Aplikasi Mobile Banking Bank Syariah Mandiri dan Bank Mandiri

\begin{tabular}{|c|c|c|c|}
\hline No & Fitur & $\begin{array}{c}\text { Bank Syariah } \\
\text { Mandiri }\end{array}$ & $\begin{array}{c}\text { Bank } \\
\text { Mandiri }\end{array}$ \\
\hline \multirow{4}{*}{1} & Informasi Rekening & $\checkmark$ & $\checkmark$ \\
\hline & -Informasi Saldo & $\checkmark$ & $\checkmark$ \\
\hline & -Daftar Mutasi & $\checkmark$ & $\checkmark$ \\
\hline & -Tanggal Mutasi & $\checkmark$ & $\checkmark$ \\
\hline \multirow{4}{*}{2} & Pembelian & $\checkmark$ & $\checkmark$ \\
\hline & -Voucher Handpone & $\checkmark$ & $\checkmark$ \\
\hline & -Indosat Prabayar & $\checkmark$ & $x$ \\
\hline & -Telkomsel & $\checkmark$ & $\checkmark$ \\
\hline \multirow{14}{*}{3} & Pembayaran & $\checkmark$ & $\checkmark$ \\
\hline & -PLN & $\checkmark$ & $\checkmark$ \\
\hline & -Telephone/Hp & $\checkmark$ & $\checkmark$ \\
\hline & -Indosat Pasca Bayar & $\checkmark$ & $x$ \\
\hline & -Telkom Pay & $\checkmark$ & $\checkmark$ \\
\hline & - Tagihan Kartu Kredit & $x$ & $\checkmark$ \\
\hline & - Bayar Angsuran & $x$ & $\checkmark$ \\
\hline & -BPJS & $x$ & $\checkmark$ \\
\hline & -Telkomsel Halo & $\checkmark$ & $\checkmark$ \\
\hline & -Akademik & $\checkmark$ & $\checkmark$ \\
\hline & -Tiket & $\checkmark$ & $\checkmark$ \\
\hline & -Asuransi & $\checkmark$ & $\checkmark$ \\
\hline & -Takaful & $\checkmark$ & $x$ \\
\hline & -Zakat/Infaq & $\checkmark$ & $x$ \\
\hline
\end{tabular}




\begin{tabular}{|c|l|c|c|}
\multirow{2}{*}{4} & Transfer & $\checkmark$ & $\checkmark$ \\
\cline { 2 - 4 } & -Non Bank & $\checkmark$ & $\checkmark$ \\
\hline 5 & Jadwal Sholat & $\checkmark$ & $\times$ \\
\hline 6 & Produk dan Promo & $\checkmark$ & $\checkmark$ \\
\hline 7 & Menu Favorit & $\checkmark$ & $\checkmark$ \\
\hline 8 & Perubahan PIN atau Bahasa & $\checkmark$ & $\checkmark$ \\
\hline 9 & Rekening Deposit & $\times$ & $\checkmark$ \\
\hline 10 & Rekening Kredit & $\times$ & $\checkmark$ \\
\hline 11 & Online Web & $\checkmark$ & $\checkmark$ \\
\hline 12 & Online Aplikasi & $\times$ & $\checkmark$ \\
\hline 13 & Cek History Transaksi & $\times$ & $\checkmark$ \\
\hline 14 & Cek History Kartu Kredit & $\times$ & $\checkmark$ \\
\hline 15 & Cek History Saldo & & \\
\hline & Top Up Isi Ulang E-Cash & $\times$ & $\checkmark$ \\
\hline 16 & Dan E-Money & $\times$ & $\checkmark$ \\
\hline 17 & Buka Deposito dan MTR & & \\
\hline
\end{tabular}

Keterangan:

$$
\begin{aligned}
\checkmark & =\text { Ada. } \\
\times & =\text { Tidak Ada. }
\end{aligned}
$$

Dari tabel 1 di atas dapat dijelaskan bahwa, mulai dari Informasi Rekening yang terdiri dari: Informasi Saldo, Daftar Mutasi, Tanggal Mutasi. Bank Syariah Mandiri dan Bank Mandiri sama-sama memiliki fitur tersebut.

Pada Pembelian: Voucher Hp, Indosat Pra Bayar, Telkomsel Fitur tersebut ada pada Aplikasi Mobile Banking Bank Syariah Mandiri namun Pembelian pada Bank Mandiri hanya ada Fitur: Voucher Hp dan Telkomsel.

Pembayaran: Adanya Fitur-fitur Aplikasi Mobile Banking Bank Syariah Mandiri hanya Pembayaran PLN, Telephon, Indosat Pasca Bayar, Telkom Pay, Telkomesl Hallo, Akademik, Tiket, Asuransi, Takaful, dan Zakat/Infaq, belum adanya pembayaran pada: Tagihan Kartu Kredit, Bayar Angsuran, BPJS. Untuk Bank Mandiri Fitur-fitur Aplikasi Mobile Banking dalam pembayaran yaitu: PLN, Telephon, Telkom Pay, Telkomesl Hallo, Akademik, Tiket, Asuransi. Bank Mandiri Tidak adanya fitur Takaful dan zakat/Infaq. Transfer untuk non bank kedua Bank Syariah Mandiri dan Bank Mandiri ada pada fitur aplikasi nya. Jadwal Sholat tidak ada pada Fitur Mobile Banking Mandiri akan tetapi ada pada fitur Mandiri Syariah.

Fitur Produk dan Promo, Menu Favorit, Perubahan PIN atau Bahasa ada pada fitur layanan Mobile Banking Bank Syariah Mandiri dan Bank Mandiri. akan tetapi pada Fitur Rekening Deposit, Rekening Kredit, Dan Online Web hanya ada pada Bank Mandiri, tidak adanya pada Bank Syariah Mandiri. Untuk mengechek Online Aplikasi, Cek History Kartu Kredit, History Saldo, History Transaksi, Top Up isi Ulang E-Cash Dan E-Money, Buka Deposito dan MTR. dari 6 Fitur ada pada Mobile Banking Bank Mandiri dan tidak ada pada Mobile Banking Bank Syariah Mandiri. 
Dari keterangan diatas fitur aplikasi pada Mobile Banking Bank Syariah Mandiri dapat dilihat banyak fitur yang tidak ada jika dibandingkan dengan fitur aplikasi mobile banking Bank Mandiri.

Kemudian berdasarkan Tarif layanan Mobile Banking Pada Bank Syariah Mandiri dan Bank Mandiri dapat dipaparkan sebagai berikut:

Tabel 2

Tarif Layanan pada Mobile Banking Bank Syariah Mandiri dan Bank Mandiri

\begin{tabular}{|c|l|c|c|}
\hline \multirow{2}{*}{ No } & \multirow{2}{*}{ Jenis Transaksi Layanan } & \multicolumn{2}{|c|}{ Biaya (Rp) } \\
\cline { 3 - 4 } & & $\begin{array}{c}\text { Bank Syariah } \\
\text { Mandiri }\end{array}$ & Bank Mandiri \\
\hline 1 & Biaya Transfer sesama Bank & Gratis & Gratis \\
\hline 2 & Biaya Bulanan perorangan & Rp. 2.500,- & Gratis \\
\hline 3 & Pembayaran tagihan PLN & Rp. 3.000,- & Rp. 3.500,- \\
\hline 4 & Transfer SKN & Rp. 5.000,- & Gratis \\
\hline 5 & Transfer RTGS & Rp. 25.000,- & Gratis \\
\hline 6 & Biaya bulanan perusahaan & Rp. 10.000,- & Rp. 25.000,- \\
\hline
\end{tabular}

Dari tabel diatas dapat dilihat jenis transaksi layanan pada aplikasi Mobile Banking Bank Syariah Mandiri dan Bank Mandiri ada 6 item jenis tarif layanan yang diberikan aplikasi Mobile Banking pada Bank Syariah dan Bank Mandiri. Aplikasi Mobile Banking Bank Syariah Mandiri terdapat 1 item yang tidak bayar (gratis) yaitu: Biaya transfer sesama bank sedangkan pada aplikasi Mobile Banking Bank Mandiri terdapat 4 item tidak berbayar yaitu: Biaya transfer sesama Bank, Biaya bulanan perorangan, SKN, RTGS. Dari pemaparan tersebut dapat dilihat tarif transaksi layanan Mobile Banking pada Bank Mandiri lebih banyak tidak berbayar dari pada Bank Syariah Mandiri, walaupun terdapat tarif yang lumayan tinggi pada layanan Bank Mandiri.

Kemudian Berdasarkan jumlah nasabah yang menggunakan aplikasi Mobile Banking Bank Syariah Mandiri KCP. Bengkalis dan Bank Mandiri KC. Bengkalis dapat dipaparkan sebagai berikut:

Tabel 3

Jumlah Nasabah Yang Menggunakan Mobile Banking pada Bank Syariah Mandiri KCP. dan Bank Mandiri KC. Bengkalis (2015-2017)

\begin{tabular}{|c|c|c|}
\hline \multirow{2}{*}{ Tahun } & \multicolumn{2}{|c|}{ Jumlah Pengguna } \\
\cline { 2 - 3 } & Bank Syariah Mandiri & Bank Mandiri \\
\hline 2015 & 141 Nasabah & 155 Nasabah \\
\hline 2016 & 150 Nasabah & 198 Nasabah \\
\hline 2017 & 173 Nasabah & 242 Nasabah \\
\hline
\end{tabular}

Dapat dilihat dari tabel 3 bahwa Bank Syariah Mandiri mengalami peningkatan jumlah pengguna mobile banking yang signifikan, begitu juga pada 
Bank Mandiri yang juga mengalami peningkatan signifikan. Dari perbandingan tabel 3 di atas jumlah nasabah yang menggunakan Mobile Banking pada Bank Mandiri KC Bengkalis lebih banyak daripada Bank Syariah Mandiri KCP Bengkalis.

Kemudian berdasarkan keamanan yang Fasilitas diberikan Mobile Banking Bank Syariah Mandiri Dan Bank Mandiri dapat dipaparkan sebagai berikut:

\section{Tabel 3 \\ Keamanan pada Aplikasi Mobile Banking pada Bank Syariah Mandiri dan Bank Mandiri}

\begin{tabular}{|c|c|c|c|}
\hline No & Keamanan & Bank Syariah Mandiri & Bank Mandiri \\
\hline 1 & Enkripsi SSL 2048 Bit & $x$ & $\checkmark$ \\
\hline 2 & Firewall & $x$ & $\checkmark$ \\
\hline 3 & $\begin{array}{l}\text { Verifikasi User Dengan } \\
\text { User Id \& Pin }\end{array}$ & $\checkmark$ & $\checkmark$ \\
\hline 4 & Auto Log Off & $x$ & $\checkmark$ \\
\hline 5 & Notifikasi Melalui Email & $x$ & $\checkmark$ \\
\hline 6 & $\begin{array}{l}\text { Notifikasi Melalui Nomor } \\
\mathrm{Hp}\end{array}$ & $x$ & $\checkmark$ \\
\hline 7 & $\begin{array}{l}\text { Menggunakan Token } \\
\text { Untuk Verifikasi } \\
\text { Transaksi }\end{array}$ & $x$ & $\checkmark$ \\
\hline 8 & Aktivasi & $\checkmark$ & $\checkmark$ \\
\hline
\end{tabular}

Keterangan:

$$
\begin{aligned}
\checkmark & =\text { Ada. } \\
\times & =\text { Tidak Ada. }
\end{aligned}
$$

Dari tabel diatas adalah keamanan aplikasi Mobile Banking yang diberikan oleh kedua bank yaitu pada Bank Syariah Mandiri dan Bank Mandiri. Menggunakan sistem keamanan Standard International dengan Enkirpsi ssl 2048 bit (Secure Socket Layer 2048 bit Encryption) yang akan mengacak data transaksi, Firewall adalah perangkat yang digunakan untuk mengontrol akses terhadap siapapun yang memiliki akses terhadap jaringan privat dari pihak luar, Firewall sebagai sistem pengatur komunikasi antar dua jaringan yang berlainan, keamanan ini ada pada Aplikasi Mobile Banking Bank Mandri saja, Verifikasi User Dengan User Id \& Pin Ser Id dan Pin Internet Banking merupakan sandi rahasia yang diberikan kepeda nasabah sebagai kewenanagan penggunaan Internet Banking, Auto Log Off adalah keluar dari Aplikasi Mobile Banking, Notifikasi Melalui Email suatu sistem notifikasi atau pemberitahuan yang dikirim melalui apabila terjadi suatu berita pesanan, Notifikasi Melalui Nomor Hp merupakan fasilitas yang dapat dinikmati asabah untuk melakukan transaksi dengan bank melalui telepon. Layanan ini mengharuskan nasabah berinteraksi dengan Customer Service Operator Bank, Menggunakan Token Untuk Verifikasi Transaksi alat pengaman untuk melakukan transaksi yang berupa Hardware, Aktivasi produk 
fisik secara online untuk internet umum yaitu proses mendapatkan kode verifikasi maupun account yang sah.

Dari penjelasan diatas maka dapat di bandingkan bahwa Bank Mandiri mempunyai 8 item keamanan yang diberikan untuk pengguna Aplikasi Mobile Banking Bank Mandiri, sedangkan Mobile Banking Bank Syariah Mandiri hanya ada 2 item keamanan yaitu: Verifikasi User Id dengan User Id dan pin serta Aktivasi. Sehingga keamanan Mobile Banking Bank Mandiri lebih aman daripada Mobile Banking Bank Syariah Mandiri.

\section{Mobile Banking Berdasarkan Perspektif Syariah}

Dari anaslisa data dijelaskan bahwa dalam transaksi Mobile Banking yang terbukti aman dengan adanya sistem proteksi yang berlapis serta memiliki perlindungan hukum. Dalam akad perjanjiam Mobile Banking telah sesuai dengan syarat sahnnya perjanjian dengan terpenuhinya rukun dan syarat akad (perjanjian). Mobile Banking GPRS (MBG) salah satunya sudah menjadi solusi untuk transaksi tersebut. Produk tersebut dalam aplikasinya menggunakan akad wakalah disertai imbalan/fee terhadap penggunaan layanan jasanya, yang berpedoman pada Fatwa DSN-MUI No.10/DSN-MUI/IV/2000 tentang wakalah. Pertama, bank bertindak sebagai wakil dari nasabah: kedua, bank bertindak sebagai wakil dari provider untuk melakukan suatu pekerjaan kemudian bank mendapatkan imbalan/fee atas pekerjaan yang dilakukan. Pada proses pengambilan fee perbankan MUI mensyaratkan diperbolehkan mengambil fee selama tidak memberatkan nasabah, dan pada bank syariah pengambilan fee bedasarkan perhitungan nominal dari keseluruhan pembiayaan.

Al-Quran dalam surat Al-Isra Ayat 35 menggariskan bawah sebuah transaksi hanya sah apabila setiap pihak yang terlibat dalam transaksi memenuhi kewajiban yang berkaitan dengan konsekuensi sebuah transaksi. Misalnya dalam transakasi yang berbentuk akad jual beli, seorang pembeli harus membyar sejumlah harga yang disepakati, sementara penjual harus menyerahakan barang yang dijualnya kepada pembeli. Begitu juga dengan demikian seseorang dapat mengakses atau melakukan transaksi Mobile Banking sah apabila setiap pihak yang terlibat dalam transaksi memenuhi kewajiban yang berkaitan dengan konsekuensi sebuah transaksi.

\section{KESIMPULAN}

Berdasarkan dari analisis data Mobile Banking Bank Syari'ah Mandiri Kantor Cabang Pembantu Bengkalis dengan Bank Mandiri Kantor Cabang Bengkalis maka penulis dapat menyimpulkan yaitu:

1. Keunggulan Mobile Banking Bank Syariah Mandiri adanya fitur berbasis islam pada aplikasi Mobile Banking yaitu tausiah dan jadwal waktu sholat, kemudian terdapat tarif layanan yang lebih murah akan tetapi untuk fitur lainnya masih belum lengkap. Mobile Banking pada Bank Mandiri sudah lengkap pada fiturnya akan tetapi untuk tausiah dan jadwal waktu sholat tidak ada dan terdapat tarif layanan yang lebih mahal.

2. Mobile Banking Bank Mandiri lebih baik dari pada Mobile Banking Bank Syariah Mandiri karena fitur-fiturnya lebih lengkap. Kemudian tarif pada aplikasi Mobile Banking Bank Mandiri lebih banyak tidak berbayar (gratis) 
dibanding aplikasi Mobile Banking Bank Syariah Mandiri. Jumlah pengguna aplikasi Mobile Banking Bank Mandiri KC Bengkalis lebih banyak di bandingkan Bank Syariah Mandiri KCP Bengkalis. Dari segi keamanan yang diberikan oleh aplikasi Mobile Banking Bank Mandiri lebih lengkap keamanannya dari pada Bank Syariah Mandiri.

3. Aplikasi Mobile Banking bila ditinjau secara islam boleh dilakukan karena tidak menimbulkan kemudharatan melainkan suatu hal yang mendatangkan banyak keuntungan, nasabah bisa melakukan transaksi kapan pun dan dimanapun.

\section{DAFTAR PUSTAKA}

Amanullah, Bastia. 2014. Pengaruh Persepsi Manfaat, Kemudahaan Penggunaan, Dan Kepercayaan Terhadap Sikap Positif Penggunaan Layanan Mobile Bangking Semarang. Skripsi. Semarang: Program Sarjana Universitas Diponegoro.

Angraini. 2012. Analisis Perbandingan Kinerja Keuangan Perbankansyariah Dengan Perbankan Konvensional (Periode 2002-2011). Skripsi. Makasar: Program Sarjana Universitas Hasanuddin.

Antonio, Muhammad Syafi'i. 2008. Bank Syariah Dari Teori Ke Praktek. Jakarta: Gema Insani.

Asmara, Alit dan Jaya. 2017. Branchless Banking. Jakarta Selatan: Penerbit Expose PT Mizan Publika.

Echols, M. Jhon. 2014. Kamus Inggris Indonesia. Jakarta: PT Gramedia.

Edwar. 2015. "Mobile Banking Berbasiskan Android Untuk Mendukung Pengembangan E-Commerce". Jurnal. Denpasar : STIKOM Bali.

Ekavidiaz. 2014. "Internet Banking di Indonesia". Jurnal. Bank dan Lembaga Keuangan Non Bank.

Hasibuan, Malayu SP. 2015. Dasar-Dasar Perbankan, Jakarta: PT Bumi Aksara.

Hendarsyah, Decky. 2012. "Keamanan Layanan Internet Banking Dalam Transaksi Perbankan”. IQTISHADUNA: Jurnal Ilmiah Ekonomi Kita, Vol.1 No.1. STIE Syariah Bengkalis.

Idrus, Muhammad. 2009. Metode Penelitian Ilmu Sosial. Yogyakarta: Erlangga.

Imaz. 2012. Permasalahan Mobile Banking Yang Terjadi Pada Perbankan Indonesia diakses dari https://imazshare.wordpress.com.

Iskandar. 2010. Metodologi Penelitian Pendidikan dan Sosial. Jakarta: GP Press.

Jumaini. 2012. Sistem Layanan Mobile Bangking Dalam Menarik Nasabah Pada PT. Bank Syari'ah Mandiri Pekanbaru Ditinjau Menurut Ekonomi Islam. Skripsi. Riau: Program Sarjana Universitas Islam Negeri.

Kementrian Agama RI. 2004. Al-Qur'an dan Terjemahannya, Bandung: Perumahan Bumi Adipura.

Karim, Adiwarman, Bank Islam, Analisi Fiqih dan Keuangan, Ed.3, Jakarta: PT. Raja Grafindo Persada.

Kasmir. 2013. Bank dan Lembaga Keuangan Lainnya. PT Raja Grafindo Persada, Jakarta.

Machmud, Amir dan Rukmana. 2010. Bank Syari'ah Teori, Kebijakan, Dan Studi Empiris Di Indonesia. Jakarta: Penerbit Erlangga. 
Mardani. 2015. Aspek Hukum Lembaga Keungan Syariah Di Indonesia. Jakarta: Prenada Media Group.

Muhammad. 2014. Manajemen Dana Bank Syariah. Jakarta: Rajawali Pers.

Pradja, Juhaya S. 2012. Ekonomi Syariah. Bandung: Pustaka Setia.

Robbiyansyah, Reza. 2014. "Internet Banking" diakses digilib.uinsby.ac.id/1090/bab2.pdf

Sebayang, Aldhisa Amanda. 2017. Pengaruh Resiko, Kemudahaan Penggunaan, Kepercayaan, Dan Electrinic Word Of Mouth Terhadap Penggunaan Layanan Mobile Banking. Skripsi. Lampung: Program Sarjana Universitas Lampung.

Silvia, Maya Angela. 2014. Faktor-Faktor Yang Mempengaruhi Minat Nasabah Yang Menggunakan Internet Bangking Pada PT Bank Rakyat Indonesia (Persero) Tbk, Cabang Ahmad Yani Makasar. Skripsi: Universitas Hassanudin.

Siregar, Syofian. 2014. Metode Penelitian Kuantitatif. Jakarta: Prenadamedia Group.

Sjahdeini, Sutan Remy. 2014. Perbankan Syariah, Produk-Produk dan AspekAspek Hukumnya Jakarta: Prenada Media Group.

Sulistriyani, Suci. 2013. "Pengaruh Minat Individu terhadap Penggunaan Mobile Banking". Jurnal. Universitas Brawijaya.

Teguh, Muhammad. 2005. Metodologi Penelitian Ilmu Ekonomi. Jakarta: Raja Grafindo Persada.

Tiwari, Rajnish dan Buse, Stephan. 2007. Prospek Perdagangan Bergerak: Analisis Peluang Strategis di Sektor Perbankan, Hamburg University Press.

Tony Marezco. Sejarah Internet Banking. (https://tonnymarezco.wordpres.com) Artikel. Akses 17 Januari 2018.

Trisni, 2012. Tinjauan Hukum Islam Terhadap SMS Banking. (eprints.ums.ac.id). Akses 4 Januari 2018

Wardhana, Aditya. 2015. "Pengaruh Kualitas Layanan Mobile Banking (MBanking) Terhadap Kepuasan Nasabah Di Indonesia”. DeReMa Jurnal Manajemen Vol 10 No. 2. Universitas Pelita Harapan.

Wibiadila, Ikbar. 2016. Pengaruh Kegunaan, Kemudahan, Reisko Dan Kualitas Layanan Terhadap Minat Nasabah Dalam Menggunakan Mobile Banking. Skripsi. Surakarta: Program Sarjana Universitas Muhammadiyah.

https://www.syariahmandiri.co.id

http://www.bankmandiri.co.id 